\title{
The Diurnal Variation of Urea in Cow's Milk and how Milk Fat Content, Storage and Preservation Affects Analysis by a Flow Injection Technique
}

\author{
By J. Carlsson and J. Bergström \\ Experimental Statıon, Veterınary Institute, Skara, Sweden.
}

\begin{abstract}
Carlsson, J. and J. Bergström: The diurnal variation of urea in cow's milk and how milk fat content, storage and preservation affects analysis by a flow injection technique. Acta vet. scand. 1994, 35, 67-77. - Six Swedish Red and White dairy cows, producing $20-39 \mathrm{~kg}$ of $4 \%$ fat-corrected milk were given a ration balanced in energy and protein. They had access to feed from 05.15 to 09.00 and from 13.00 to 16.30 and were milked at 06.15 and 15.30 . The milk was analysed for urea with a FIA technique.

There was a significant diurnal variation in milk urea. The highest values were found 3-5 $\mathrm{h}$ after the beginning of the morning feeding and the lowest values (down to $60 \%$ of the max. values) during late night. Within $1 \mathrm{~h}$ after the start of the morning feeding the urea values had increased significantly, but they had decreased withın the same tıme after the start of the afternoon feeding. Since there was a pronounced diurnal var1ation in the milk fat content, the urea concentration was also recalculated to concentration in the water phase of the milk. It was higher in that phase, but the pattern of the diurnal variation was not changed significantly. However, analyses on milk with a very high fat content may give misleading results.

There were no important differences in the milk urea concentration of different udder quarters. When calculated as concentration in the water phase of the milk, no differences in urea concentration were found between the beginning and the end of milking. The analytical method had a good precision (coefficient of variation max. 3\%). The milk urea concentration was not changed significantly after storage during 10 days at $4^{\circ} \mathrm{C}$ when no preservative was added; but after 17 days the milk had turned sour and the urea value had increased. When a preservative (bronopole) was added the urea concentration remained unchanged during 17 days. Deepfreezing did not influence the urea concentration.
\end{abstract}

milk urea; milk profile test; FIA-technique; milk components; dairy cows.

\section{Introduction}

In recent years there has been growing interest in using the concentration of urea in milk not only as an indicator of the efficiency with which protein is being fed to dairy cows but also of the balance between the energy and protein in their diet (Kaufmann 1982, Oltner \& Wiktorsson 1983, Gustafsson et al. 1987, Ropstad et al. 1989, Hoffmann \& Steinhöfel
1990, Miettinen \& Juvonen 1990, Gustafsson $\&$ Carlsson 1993). In addition to the routine analyses for milk fat and protein, and cell counts, the Swedish dairy industry can now provide farmers and nutritional advisers with inexpensive analyses of milk urea, in samples from individual cows or from the bulk milk tank. However, for the correct sampling and 
interpretation of urea values from individual cows it is necessary to gain a knowledge about its diurnal variation. Further, it is essential to know how the analysis is affected by other milk components and by the methods for sampling, handling and, when necessary, storing and preserving the milk sample before it is analysed.

Oltner \& Wiktorsson (1983) and Miettinen \& Juvonen (1990) found that milk urea concentration was slightly higher in the afternoon milk (15.30) than in the morning milk (06.30). In both trials the cows were fed twice daily at unequal intervals (06.00 and 14.00) and furthermore the interval between the afternoon and morning milkings was longer (14 to $15 \mathrm{~h}$ ) than the interval between the morning and afternoon milking (9 to $10 \mathrm{~h}$ ). In contrast, when cows were fed equal portions of their daily rations twice a day at intervals of $12 \mathrm{~h}$ the concentration of urea in milk showed 2 equal peaks, each occurring a few hours after the start of the feeding periods (Ciszuk, unpublished).

Gustafsson \& Palmquist (1993) reported that a small sample of milk taken from a healthy quarter of the udder at any time of the day may be as good for an analysis of the urea concentration as a sample taken from a normal milking at the same time. Hoffmann \& Steinhöfel (1990) found that there were no differences between the urea concentrations of milk samples taken at the beginning, the middle and the end of a single milking, whereas Haag (1988) found the lowest milk urea concentration at the end of a single milking. Wolfschoon-Pombo (1981) found that mastitis can influence the urea concentration in a quarter sample.

The aims of the present study were to examine in more detail the effects on milk urea concentration of diurnal variations, the effects of variations between quarters and between samples taken at different times during a milking, the variations within and between the analyses of batches of milk samples and the effects on these variations of different periods of storage either with or without preservative, and finally the effects of variations in the fat content of the milk. It was hoped that these results would help to make the interpretation of milk urea concentrations more useful and reliable.

\section{Materials and methods}

\section{Animals and feeding}

Six cows of the Swedish Red and White breed were used. Three of them had calved between 13 and 24 weeks earlier and were producing $36.0,36.7$ and $38.5 \mathrm{~kg} \mathrm{4 \%}$ fat-corrected milk (FCM) per day, and the other 3 had calved between 46 and 54 weeks earlier and were producing 20.4, 21.1 and $21.9 \mathrm{~kg}$ FCM per day. All the cows were tied in stalls and fed $2.0 \mathrm{~kg}$ hay, $7.0 \mathrm{~kg}$ dry matter of grass silage, $2.0 \mathrm{~kg}$ dried beet pulp and $150 \mathrm{~g}$ of a standardized, vitaminized mineral supplement daily. In addition they were fed oats and a commercial protein feedstuff in relation to their milk production according to Swedish standards, ie, for maintenance: 0.507 MJ metabolizable energy (ME) per kg bodyweight ${ }^{075}$ and 6.2 g digestible crude protein (DCP)/MJ ME, and for production: 5.0 MJ ME and $60 \mathrm{~g} \mathrm{DCP} / \mathrm{kg}$ FCM. The feed gates were open from 05.15 to 09.00 and from 13.00 to 16.30 and they were milked at 06.15 and 15.30 daily. There were no feed refusals. Samples were taken from 10.00 on day 1 to 10.00 on day 2 . The feeding routines and sampling times are shown diagramatically in Fig. 1.

\section{Diurnal variations}

The first $50 \mathrm{ml}$ of milk from the left front quarter of each cow were sampled every $h$ from 10.00 to 19.00 on the first day and at 


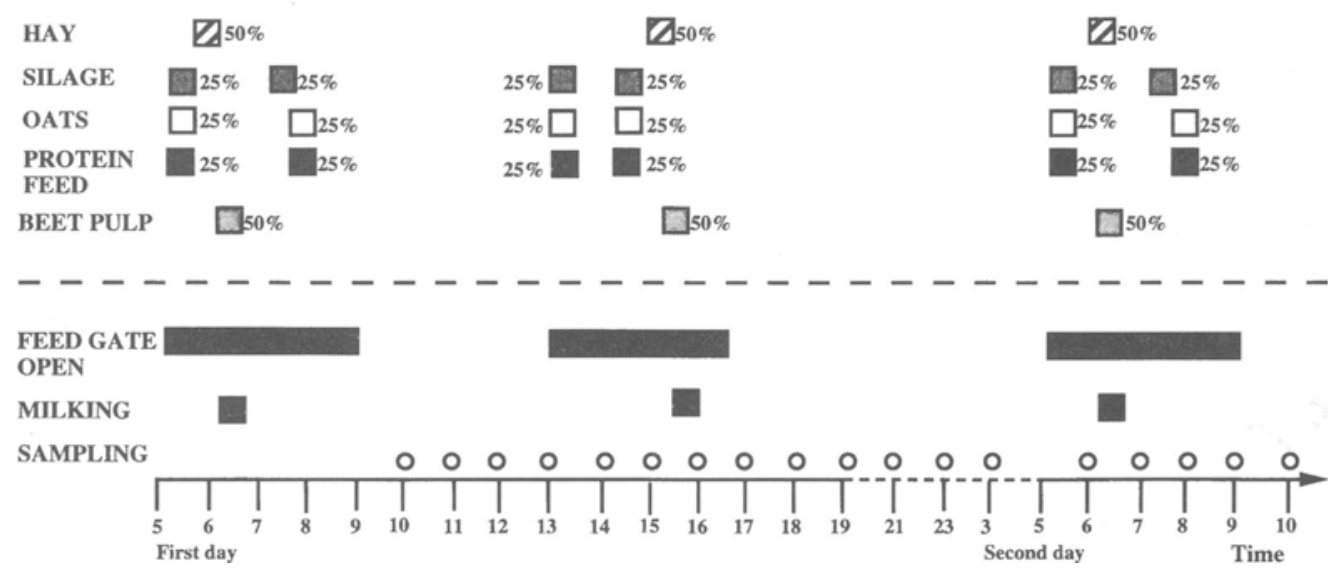

Figure 1. The feeding regimens, giving the \% of the total daily amounts of each feedıngstuff, the milking tımes and the sampling times for the 6 cows.

longer intervals during the night, and from 06.00 to 10.00 on the second day (Fig. 1).

\section{Variations between quarters}

One milk sample was taken from each quarter of each cow at 15.00 on the first day.

\section{Variations during milking}

At the 15.30 milking on the first day three 50 ml sample of milk was taken from each cow, the first from the strippings (fraction 1), the second when the udder was approximately half empty (fraction 2) and the third from the residual milk when normal milking had finished (fraction 3).

Precision of the method and variations due to storage and preservation

A fresh sample of bulk milk was divided into 4 parts which were treated as follows:

a) Stored at $4^{\circ} \mathrm{C}$ with no preservative

b) Stored at $4^{\circ} \mathrm{C}$ and preserved with bronopole

c) Stored at $-20^{\circ} \mathrm{C}$ with no preservative

d) Stored at $-20^{\circ} \mathrm{C}$ and preserved with bronopole.
For each treatment a sample was analysed 40 times on each of the days 3, 5 and 10 after sampling. Replicates for each treatment were analysed in 1 sequence during each day. For treatments a) and b) similar replicate analyses were also done on the day of sampling and on the fifth and 17th day after sampling.

\section{Influence of fat content}

In order to investigate the influence of fat content on the analytical method, a series of water based standards containing different amounts of fat, but all $6 \mathrm{mmol} / \mathrm{l}$ with respect to urea, were prepared. $2 \mathrm{ml}$ samples of 30 $\mathrm{mmol} / \mathrm{l}$ aqueous urea solution were diluted to a final volume of $10 \mathrm{ml}$ with different volumes of water and cream containing $40 \%$ fat. For example, the standard containing $8 \%$ fat was prepared by adding $6 \mathrm{ml}$ of water and $2 \mathrm{ml}$ of the cream to $2 \mathrm{ml}$ of $30 \mathrm{mmol} / \mathrm{l}$ urea solution. Four standards were prepared for each 1 percent increment in fat content from $0 \%$ to $8 \%$. Two of the standards were centrifuged in order to remove the fat and 2 were kept with the fat evenly distributed in the solution. All standards were then analysed with respect to urea. 
A blank standard prepared from $8 \mathrm{ml}$ of water and $2 \mathrm{ml}$ cream (not centrifuged) was found to contain 0.4 to $0.5 \mathrm{mmol} / \mathrm{l}$ urea.

\section{Analytical methods}

Urea was analysed by the flow injection analysis (FIA) technique of Andersson et al. (1986). Fat, protein and lactose were analysed by the conventional infrared (IR) technique, at a dairy laboratory. All analyses on milk samples from individual cows were done once for each analyte, without replicates. For the urea analyses a 4-point calibration curve was established when necessary, i.e. at the beginning of each day and when a reagent or the gas diffusion membrane was replaced. All the samples were mixed thoroughly to distribute the milk fat evenly before they were analysed.

\section{Statistical analyses}

The SAS computer program package was used for all the calculations (SAS Institute Inc. 1987). Proc Anova was used for anovas, proc Means was used to calculate means and standard deviations, and proc Reg for regressions. The diurnal variations in the concentrations of protein and lactose were evaluated by testing the null hypothesis that the concentrations on all sampling occasions were the same, using a one-way anova with time of day as the only factor. Diurnal variations of milk fat and milk urea were not analysed statistically, as their patterns of variation are obvious from Figs. 2, 3 and 4.

Differences between samples taken at different times during milking (fractions 1 to 3 ) were also analysed using a one-way anova with fraction as only factor.

The method precision was calculated as standard deviation for each bulk milk treatment on each day, i.e. on 40 replicates. The total precision over several series was calculated as the standard deviation of all series for each treatment, except those on day 17 , when unpreserved milk had turned sour. Differences between treatments were evaluated using proc Anova.

The change of urea concentraion in bulk milk samples with storage time was evaluated using a simple regression of urea with time as independent variable. The mean value for each day for each of the 4 treatments was used since all determinations for each day depend on the calibration curve determined that day. Similarily, when investigating the influence of the treatments on the analysis the mean value for each treatment for each of the days 3,5 and 10 was used in a one-way anova with urea as dependent on treatment.

\section{Results}

\section{Diurnal variation}

The mean ( $\pm \mathrm{sd}$ ) concentration of urea in the 108 samples (6 cows $\times 18$ samples) was 4.53 $\pm 0.88 \mathrm{mmol} / \mathrm{l}$, with a range from 2.9 to 6.9 $\mathrm{mmol} / \mathrm{l}$.

The 6 cows all showed the same diurnal pattern of variation (Fig. 2) with high plateau values 3 to $8 \mathrm{~h}$ after the start of the morning feeding period (mean peak value $5.52 \mathrm{mmol} / \mathrm{l}$ ) and the lowest values between late evening and early morning (mean lowest value 3.35 $\mathrm{mmol} / \mathrm{l}$ ). At 06.00 , only $45 \mathrm{~min}$ after the start of the morning feeding period, the milk urea concentration had already increased considerably. The mean urea concentrations at 10.00 on the first and second days were the same: $5.37 \mathrm{mmol} / \mathrm{l}$. In contrast with the increase in milk urea concentration after the beginning of the morning feeding period there was a decrease in the urea concentration after the beginning of the afternoon feeding period.

There was a wide variation in milk fat content during the day (Fig. 3), with the lowest values occurring just before the cows were milked 


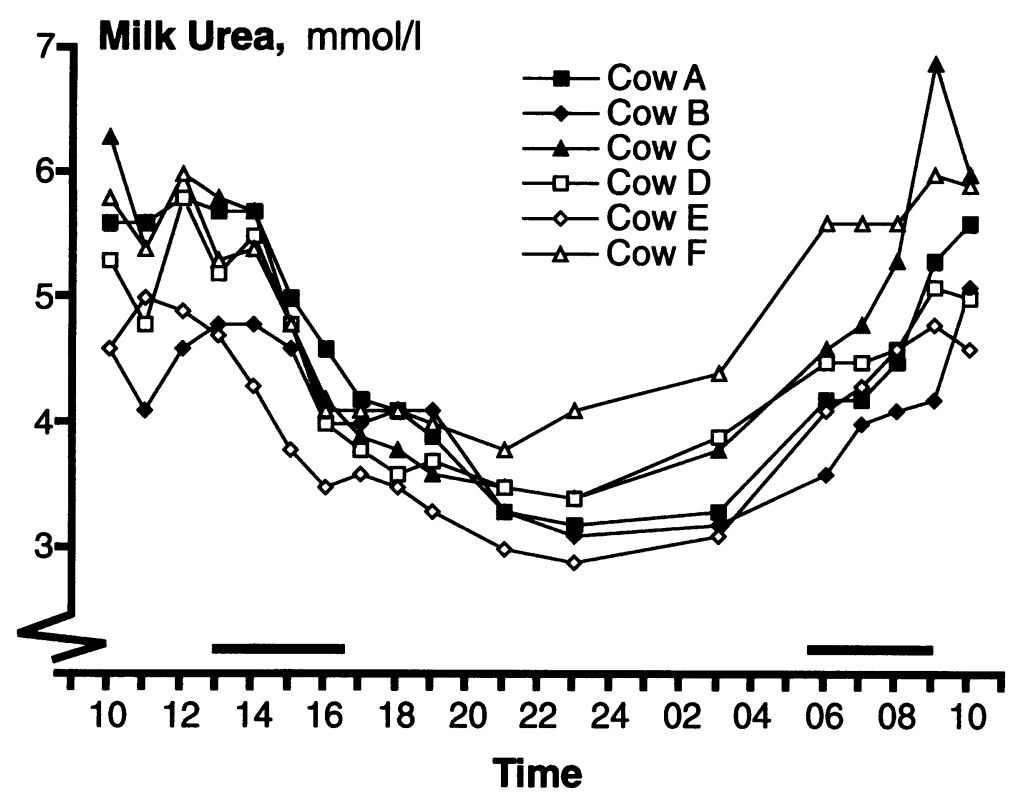

Figure 2. The urea concentrations in samples of milk taken from 6 cows on 18 occasions between 10.00 on the first day and 10.00 on the second day. Bars along the time axis indicate feedgate open. Cows A, B and C produced on average $37 \mathrm{~kg}$ FCM/day and cows D, E and F produced on average $21 \mathrm{~kg} \mathrm{FCM} /$ day.

(lowest mean value $1.1 \%$ at 06.00 ) and the highest values during the first few $\mathrm{h}$ after milking (highest mean value $11.9 \%$ at 07.00 ). The content of fat in the milk affects the apparent concentration of urea in whole milk because the urea is dissolved only in the water phase of the milk. The milk urea concentration was therefore recalculated as the concentration of urea in the water phase. As a result the adjusted urea concentrations were all higher than the unadjusted values (Fig. 4), but the general shape of the curve of diurnal variation was unchanged.

The concentrations of protein and lactose in whole milk also varied significantly during the day; the maximum and minimum values for protein were $3.53 \%$ and $2.87 \%$ at 03.00 and 07.00 respectively, and those for lactose were $4.66 \%$ and $3.77 \%$ at 06.00 and 07.00 respectively. However, the anova revealed no signif- icant differences over time for either constituent after the concentrations had been corrected, as for urea, for the fat content of the milk.

\section{Variations between quarters}

The mean concentrations of urea in the milk from all 4 quarters of each of the 6 cows were $4.05,4.58,4.80,4.85,4.89$ and $5.05 \mathrm{mmol} / \mathrm{l}$, and the largest differences between any pair of quarters in the 6 cows were $0.2,0.2,0.4,0.1,0.0$ and $0.3 \mathrm{mmol} / 1$ respectively. No systematic differences were found between the front and hind or between the left and right quarters.

\section{Variations during milking}

The mean urea concentrations of the milk taken from the 6 cows at the afternoon milking were $4.03,4.20,4.37,4.43,4.50$ and 4.70 $\mathrm{mmol} / \mathrm{l}$, and the largest differences between 


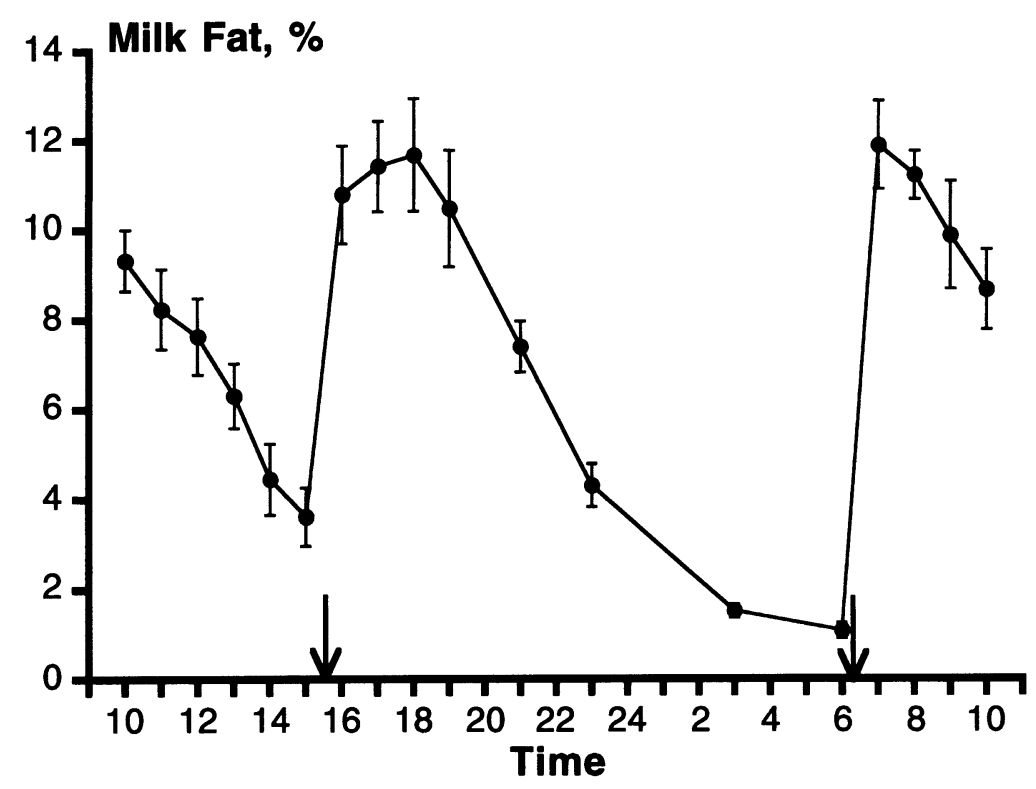

Figure 3 The mean ( \pm se) milk fat concentrations in samples taken from 6 cows on 18 occasions between 10.00 on the first day and 10.00 on the second day. Arrows indicate milkıng tımes.

any of the 3 fractions taken during the milking were $0.4,0.4,0.6,0.2,0.5$ and $0.8 \mathrm{mmol} / 1 \mathrm{re}-$ spectively. Five of the cows had the lowest urea concentration in fraction 3 and 5 had the highest concentration in fraction 1 . These differences were statistically significant in the anova $(\mathrm{P}<0.05)$. However, when the concentration of urea was calculated as the concentration in the water phase, no significant differences remained.

The content of fat was highest in fraction 3 (mean 10.14\%) and lowest in fraction 1 (mean $3.26 \%$ ), and the concentrations of protein and lactose varied significantly $(\mathrm{P}<0.05)$ in the opposite direction; the highest concentrations of protein and lactose (mean values $3.71 \%$ and $4.72 \%$ respectively) occurred in fraction 1 , and the lowest (mean values $3.23 \%$ and $4.27 \%$ respectively) occurred in fraction 3 . However, these differences were eliminated when the concentrations were calculated as the concentrations in the water phase of the milk.

\section{Variations due to preservation and storage}

The regression analysis revealed no tendency for the milk urea concentration to change during the first 10 days. Neither did an anova reveal any differences between treaments. By the 17 th day the unpreserved milk was distinctly sour and its urea concentration had increased from $5.7 \mathrm{mmol} / 1$ to $7.5 \mathrm{mmol} / \mathrm{l}$, but the concentration of urea in the sample preserved with bronopole had not changed.

\section{Precision of the method}

The within series standard deviation ranged from 0.08 to $0.17 \mathrm{mmol} / 1$ with an average of $0.12 \mathrm{mmol} / \mathrm{l}$, corresponding to a coefficient of variation of $2.1 \%$. The total standard devia- 


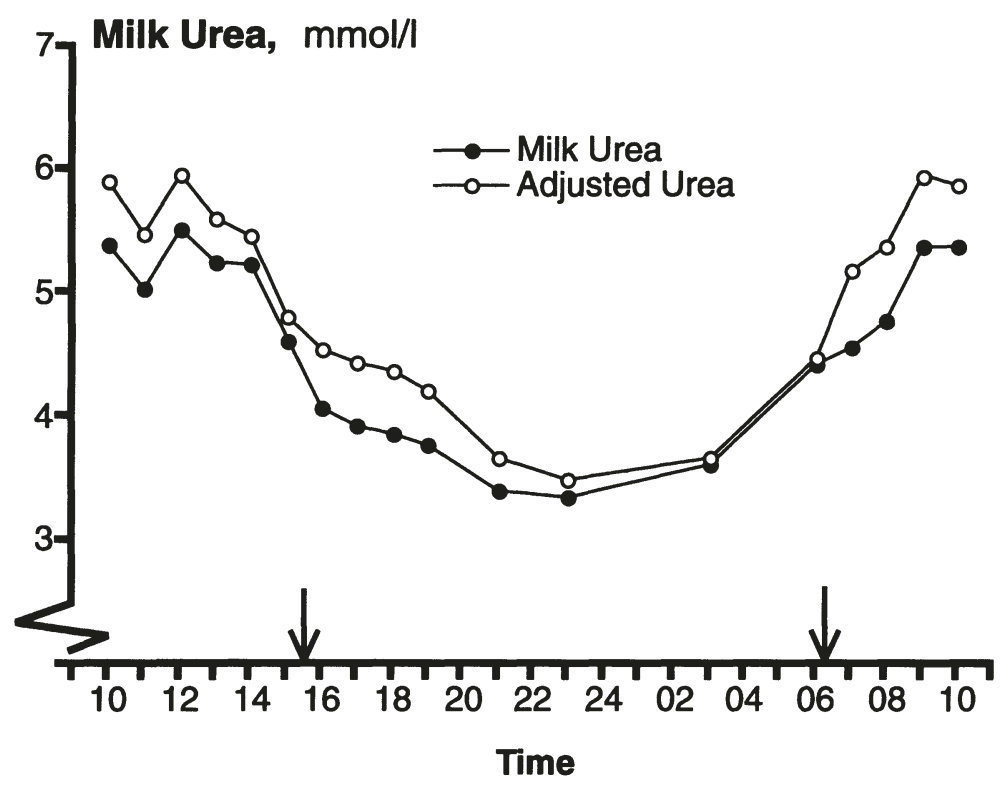

Figure 4. The mean unadjusted milk urea concentration and the mean milk urea concentration adjusted for fat concentration in milk samples taken from 6 cows on 18 occasions between 10.00 on the first day and 10.00 on the second day. Arrows indicate normal milkıng tımes.

tion mesured over several series ranged from $0.13 \mathrm{mmol} / \mathrm{l}$ to $0.17 \mathrm{mmol} / \mathrm{l}$ for the 4 treatments with an average of $0.16 \mathrm{mmol} / \mathrm{l}$ which corresponds to a coefficient of variation of $2.8 \%$.

\section{Effect of fat content}

A regression analysis of the change in the apparent urea concentration ( $\mathrm{Y} \mathrm{mmol} / \mathrm{l})$ of aqueous samples containing $6.0 \mathrm{mmol} / \mathrm{l}$ urea, as their fat content $(\mathrm{X} \%)$ increased, gave the equation:

$$
\mathrm{Y}=6.0+0.065 \mathrm{X} \quad \text { (Fig. 5, line A) }
$$

At $8 \%$ fat content the slope of this equation results in an increase in urea concentration of $0.52 \mathrm{mmol} / \mathrm{l}$. Analysis of samples containing only water and $8 \%$ fat from cream were found to contain 0.4 to $0.5 \mathrm{mmol} / \mathrm{l}$ urea.
When the samples were centrifuged, and the skimmed milk analysed the regression equation was:

$$
\mathrm{Y}=6.0+0.175 \mathrm{X} \quad \text { (Fig. 5, line B) }
$$

This regression coefficient is higher than the regression coefficient of approximately 0.12 , which would have been expected as a result of the effect of the volume of pure fat on the apparent urea concentration of the aqueous samples (Fig. 5, line C).

\section{Discussion}

In accordance with the report by Gustafsson \& Palmquist (1993) there was considerable diurnal variation in the milk urea concentration. It has been found in several trials that the changes in milk urea concentration are closely 


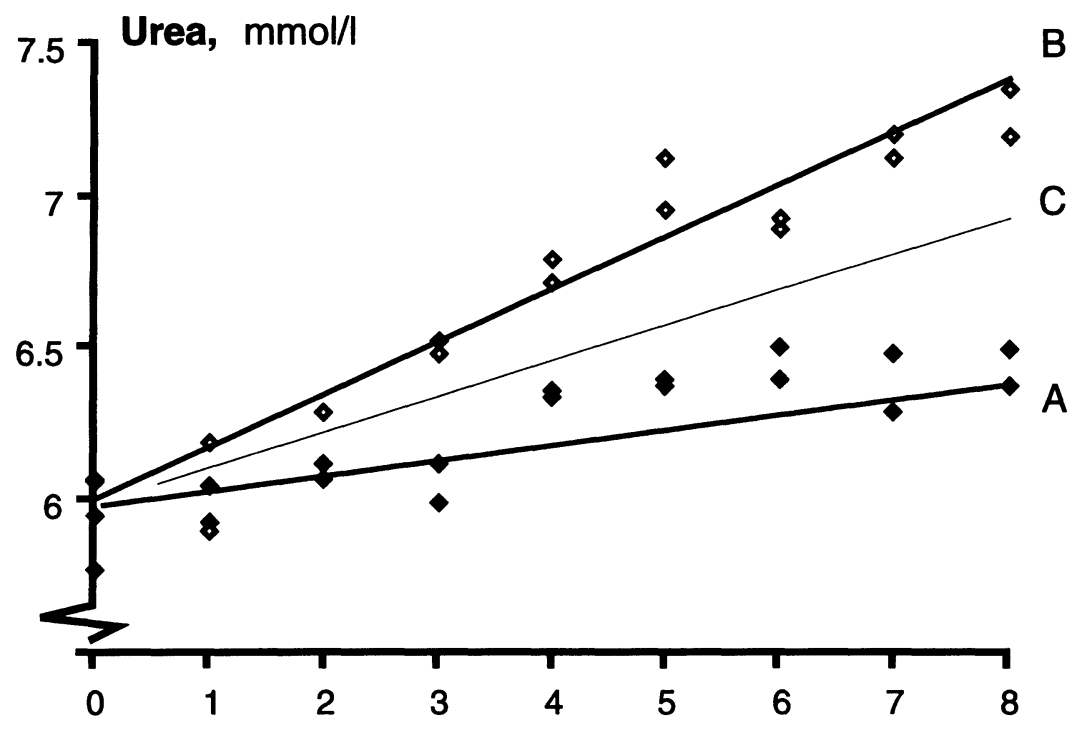

Fat, \%

Figure 5. The effect on milk urea concentratıon of changing milk fat concentration. Cream was added to aqueous urea samples containing $6 \mathrm{mmol} / \mathrm{l}$ urea. A: Standards analysed before centrifugation (the increase in the urea concentration was due to the urea contained in the cream). B: Standards analysed after centrifugation. $\mathrm{C}$ : The change in the concentration of urea to be expected if the urea had been evenly distributed throughout the aqueous fraction of the milk.

correlated with the changes in blood urea concentration (Beutlhauser 1982, Oltner \& Wiktorsson 1983, Refsdal 1983, Miettinen \& Juvonen 1990) which in turn are correlated, after a lag of a few $\mathrm{h}$, with the changes in the concentration of ammonia in the rumen (Folman et al. 1981, Hammond 1983, Blauwiekel \& Kincaid 1986, Carroll et al. 1988, Carlsson \& Pehrson 1994). As expected there was an increase in the milk urea concentration after the morning feed, but there was an unexpected decrease after the afternoon feed. However, a similar pattern was also observed by Ciszuk (unpublished) when cows were fed twice a day at the same unequal intervals as in the present investigation, whereas when the cows were fed at regular intervals of $12 \mathrm{~h} 2$ identical peaks of milk urea concentration were ob- served. There are presumably undefined factors, such as the excretion of urea in the urine or other homeostatic processes, which control the relationship between rumen ammonia concentration and milk urea concentration. It is also possible that some of the milk urea may be derived from sources other than rumen ammonia.

In spite of the wide range $(1.1 \%$ to $11.9 \%$; Fig. 3 ) in the fat contents of the milk between samplings, the shapes of the curves describing the diurnal variations in milk urea concentrations, measured either directly or after being corrected for the milk fat content, were similar (Fig. 4). Misleading values could, however, be obtained at very high fat levels. Bulk milk should therefore be thoroughly mixed before sampling, and spot samples taken out after the 
ordinary milkings should be avoided since fat content was much higher in fraction 3 of milking than in fraction 1 , which was in accordance with results published by Haag (1988).

When correlations between rumen metabolites and milk urea are to be studied, a preferable time for milk sampling should be when peak values of milk urea can be expected. The present study also shows that routine samples from the monthly control milking (based on an equal mixture from the afternoon and morning milkings) can not be equalized with samples from single cows taken out by handstripping at another time of the day. It is important, particularly for a research project and in comparisons within herds, that samples of milk for the measurement of urea concentration should be taken at the same time relative to the times of feeding and normal milking of the cows. Because of the influence of fat on the urea concentration it is also important to homogenize the sample before analysis so that the part of the sample that is actually injected into the flow system is representative of the whole sample. Furthermore, in detailed scientific studies, it may be prudent to remove the milk fat by centrifugation before the sample is analysed, because different results are obtained when samples are analysed either with or without the fat present. Fig. 5 shows, however, that centrifugation affected the results more than would have been expected simply as a result of the effect of the volume of milk fat. The difference may have been due to the fact that the water still associated with the emulsion of milk fat may be free of urea.

The feeding and milking times used in the study were similar to those used by most Swedish dairy herds, particularly those with the cows kept tied in stalls. They did not appear to cause any large differences between the urea concentrations in the milk from the ordinary morning and afternoon milkings.
However, Fig. 2 indicates that if the morning milking had been delayed by $2 \mathrm{~h}$ the concentration of urea in the morning sample would have been between 1 and $1.5 \mathrm{mmol} / \mathrm{l}$ greater than in the sample taken in the afternoon.

There were only small differences between the concentrations of urea in milk samples taken from the 4 quarters of the udder. Milk samples can therefore be taken from any of the quarters, although sampling from infected quarters should be avoided as a changed permeability of cell mebranes may affect the milk urea concentration (Wolfschoon-Pombo 1981).

The FIA technique for the determination of milk urea concentrations has a high capacity and can easily be added to the routine milk analyses carried out at a dairy (Andersson et al. 1986). Further evidence of its good precision is provided by the coefficients of variation of $2-3 \%$ observed in this study. The major part of the between-day variance is probably due to differences between calibrations. The 4 calibration readings are subject to the same variation as the milk samples: if desired the between-calibration variance can be reduced by using more readings to construct the calibration curve.

The results of this investigation indicate that the concentration of urea in milk is stable for at least a week when the sample is stored at + $4^{\circ} \mathrm{C}$. A milk sample that has turned sour should be discarded, as souring affects urea concentration. Preservation by addition of bronopole or by freezing increases storage stability without affecting the result of the analysis.

Milk is a convenient test medium, as samples from the bulk tank are sent to the dairies once a week and samples from individual cows are sent once a month. Milk samples taken either from individual cows or from the bulk tank are therefore easily accessible for the routine 
monitoring of the feeding regimens of dairy herds. When studying individual cows it is necessary to standardise the time of day when samples are taken, as the urea concentration varies considerably over the day. However, on most farms the milking time is well standardised so that monthly control milk samples taken during the ordinary milkings are comparable with each other.

\section{Acknowledgements}

The investigation was supported by the Swedish Farmers' Foundation for Research.

\section{References}

Andersson G, Andersson L, Carlstrom G: Determination of milk urea by Flow Injection Analysis. J. Vet. Med. A, 1986, 33, 53-58.

Beutlhauser B: Harnstoffkonzentration in Milch und Korperflussigkeiten bel Hochleistungskuhen. (Milk urea concentration in milk, and body fluids in high yielding dairy cows). Thesis, University of Munich, Germany, 1982.

Blauwlekel $R$, Kincaid RL. Effect of crude protein and solubility on performance and blood constituents of dairy cows J. Dairy Sc1. 1986, 69, 20912098.

Carlsson J, Pehrson B: The influence of the dietary balance between energy and protein on milk urea concentration. Experimental trials assessed by 2 different protein evaluation systems. Submitted for publication in Acta vet. scand.

Carroll DJ, Barton BA, Andersson GW, Smith RD: Influence of protein intake and feeding strategy on reproductive performance of dairy cows. J. Dairy Sc1. 1988, 71, 3470-3481.

Folman Y, Neumark H, Kaim M, Kaufmann W: Performance, rumen and blood metabolites in highy1elding cows fed varying protein percents and protected soyabean. J. Dairy Sci. 1981, 64, 759768.

Gustafsson AH, Carlsson J: Effects of silage quality, protein evaluation systems and milk urea content on milk yield and reproduction in dairy cows. Livest. Prod. Sci. 1993, 37, 91-105.

Gustafsson AH, Emanuelson M, Oltner R, Wiktorsson $H$ : Mjolkens ureahalt, dess variation och påverkan av besattning, mjolkavkastning, lakta- tıonsstadium, sasong och utfodring. (Milk urea level, its variations and how it is affected by herd, milk yield, stage of lactation, season and feeding - a field study). Report No. 165. Department of Animal Nutrition and Management. Swedish Unıversity of Agricultural Sciences, Uppsala 1987.

Gustafsson AH, Palmquist DL: Diurnal variation of rumen ammonia and serum and milk urea in dairy cows at high and low yıeld. J. Dairy Scı. 1993, 76, 475-484.

Haag $T$ : Zum Aussagewert der Harnstoffbestımmung in der Milch vom Rind unter besonderer Berucksichtıgung methodischer Untersuchungen. (The value of milk urea determinations in dairy cows with special reference to methodological studies). English summary. Thesis, JustusLiebig-University, Giessen, Germany, 1988.

Hammond, AC. Effect of dietary protein level, ruminal protein solubility and time after feeding on plasma urea nitrogen and the relationship of plasma urea nitrogen to other ruminal and plasma parameters. J. Anım. Scı. 1983, 57, suppl. $1,435$.

Hoffmann $M$, Steinhofel $O$. Moglichkeiten und Grenzen zur Einschatzung der Energie- und Proteinversorgung durch Kontrolle des Milchharnstoffgehaltes. (Possibilities and restrictions for evaluation of the dietary energy and protein balance by analysis of the milk urea concentration). Mh. Vet. Med. 1990, 45, 223-227.

Kaufmann W. Variation in der Zusammensetzung des Rohstoffes Milch unter besonderer Berucksichtigung des Harnstoffgehaltes. (Variations in the composition of milk with special reference to the urea concentration). Milchwissenschaft 1982, 37, 6-9.

Miettinen PVA, Juvonen RO: Diurnal variations of serum and milk urea levels in dairy cows. Acta agric. scand. 1990, 40, 289-296.

Oltner $R$, Wiktorsson $H$ : Urea concentrations in milk and blood as influenced by feeding varying amounts of protein and energy to dairy cows. Livest. Prod. Sc1. 1983, 10, 457-467.

Refsdal $A O$ : Urea in bulk milk as compared to the herd mean of urea in blood. Acta vet. scand. 1983, 24, 518-520.

Ropstad E, Vik-Mo L, Refsdal AO: Levels of milk urea, plasma constituents and rumen liquid ammonia in relation to the feeding of dairy cows during early lactation. Acta vet. scand. 1989, 30, 199-208. 
SAS Institute Inc. SAS/STAT Guide for personal computers, Version 6 Edition. Cary, NC, 1987.

Wolfschoon-Pombo $A F$. Untersuchungen uber die Menge und Zusammensetzung der sogenannten NPN in Milch. (Investigations on the amount and composition of NPN in milk). Thesis, Un1versity of Munich, Germany 1981.

\section{Sammanfattning}

Dygnsvariation 1 mjolkens ureakoncentration hos mjolkkor och hur mjolkfetthalten, lagring och konserveringsmedel påverkar analysen med flow injectıon-teknık

Sex SRB-kor med en daglig avkastning på 20-39 kg 4\%-1g mjolk erholl en med avseende på energı och protein balanserad foderstat. De hade tillgång till foder kl. 05.15 till 09.00 och 13.00 till 16.30. Mjolkning skedde kl. 06.15 och 15.30. Mjolkens ureahalt analyserades med FIA- teknık.

Det forelåg en betydande dygnsvariation 1 mjolkureakoncentration. De hogsta vardena uppmattes 3-
8 tımmar efter morgonutfodrıngens start och de lagsta (ned tıll $60 \%$ av max.vardena) under sen kvall och natt. Inom en timma efter morgonutfodringens start hade vardena stigit avsevart. Daremot sjonk vardena inom samma tidsrymd efter eftermiddagsutfodringens start. Eftersom mjolkens fetthalt varierade kraftigt under dygnet beraknades också ureahalten 1 mjolkens vattenfas. Halten var hogre 1 vattenfasen, men monstret for dygnsvariationen forandrades inte namnvart. Dock kan analysen på mjolk med mycket hog fetthalt ge missvisande resultat.

Det forelåg inga betydelsefulla skıllnader 1 ureahalt mellan olıka juverdelar. Halten var något hogre 1 den forsta an 1 den sista fraktionen vid varje mjolkning. Analysmetoden hade en god precision (variationskoefficient max 3\%). Mjolkens ureahalt uppvisade inga sıgnıfikanta forandrıngar efter lagring utan tıllsats av konserverıngsmedel vid $+4^{\circ} \mathrm{C}$ under 10 dagar. Efter 17 dagar hade mjolken surnat och ureavardet stigit. Vid tillsats av bronopol forblev ureahalten oforandrad efter 17 dagars forvarıng vid $+4^{\circ} \mathrm{C}$. Djupfrysning påverkade inte ureavardet.

(Recelved November 7, 1993; accepted November 22, 1993).

Reprints may be requested from: J. Carlsson, Veterınary Institute, Experımental Statıon, P.O. Box 234, S-532 23 Skara, Sweden. 
